\title{
Natural to anthropogenic forcing in the Holocene evolution of three coastal lagoons (Caldas da Rainha valley, western Portugal)
}

\author{
J.L. Dinis ${ }^{\mathrm{a}, *}$, V. Henriques ${ }^{\mathrm{b}}$, M.C. Freitas ${ }^{\mathrm{c}}$, C. Andrade ${ }^{\mathrm{c}}$, P. Costa $^{\mathrm{a}, \mathrm{d}}$ \\ ${ }^{a}$ Department of Earth Sciences and Geosciences Center, University of Coimbra, Largo Marquês de Pombal, $3000-272$ Coimbra, Portugal \\ ${ }^{\mathrm{b}}$ Department of Geosciences, University of Évora, Rua Romão Ramalho 59, 7002-554 Évora, Portugal \\ ${ }^{\mathrm{c}}$ Laboratory of Coastal Processes, Centre of Geology and Department of Geology, Faculty of Science, University of Lisbon, Bloco C6, $3^{\circ}$ Piso, \\ Campo Grande, 1749-016 Lisboa, Portugal \\ ${ }^{\mathrm{d}}$ Department of Geography and Earth Sciences, Brunel University, Uxbridge UB8 3PH, Middlesex, UK
}

Available online 13 March 2006

\begin{abstract}
In the coast of Central Portugal three lagoons were created by the Holocene flooding of diapiric-related depressions but experienced afterwards a significant sediment accumulation. Fast environmental and morphological changes after the Middle Holocene were clearly forced by anthropogenic activities since the Middle Ages and show a strong feedback on the human communities. Erosion in the studied watersheds depends on climatic and anthropic changes; especially, demographic rises increase agriculture and deforestation in the watersheds, and sedimentation in the lagoons. The region was successively occupied by ethnic groups since the Neolithic (including Romans, Sueves, Visigoths and Muslims), but the main changes were largely due to anthropic forcing following the Christian Reconquest by the Kingdom of Portugal. In fact, during the Middle Ages and Renaissance the area had intense nautical, fishing and agricultural activities, even if reduced during the 14th century crisis. Later, due to severe sediment accumulation and shoaling, sailing was drastically reduced and most of the area drowned in the maximum transgression was claimed to farming. It is also noteworthy that the social evolution and sediment entrainment in the watersheds appear to be in tune with climatic trends deduced after regional and global data. In synthesis, we conclude that the human activities during the last millennium greatly accelerated the natural silting trend of the lagoons.
\end{abstract}

(C) 2006 Elsevier Ltd and INQUA. All rights reserved.

\section{Introduction}

Historically, the different uses of the land by mankind reflect its organisation as a society keeping an anthropocentric view of Nature and with short-term economic logic. To justify environmental conservation and the respect for natural phenomena as key issues on land use policy, the recent natural or human driven rapid and/or catastrophic changes must be studied and disseminated among policy makers and the public. As in the presented case study, the social memory is usually rather short, and even deep changes affecting the economic and social structures can be unknown from the huge majority of the inhabitants of the region.

\footnotetext{
${ }^{*}$ Corresponding author. Fax: + 351239860501.

E-mail addresses: jodinis@dct.uc.pt (J.L. Dinis), virginia@uevora.pt (V. Henriques), cfreitas@fc.ul.pt (M.C. Freitas), candrade $@$ fc.ul.pt (C. Andrade), pedrojmcosta@hotmail.com (P. Costa).
}

The aim of the present paper is to contribute to enlighten the details of the fast environmental and morphological changes since the Middle Holocene of a coastal region, clearly forced by anthropogenic activities since the Middle Ages but with a strong feedback on the human communities.

Sediment entrainment in watersheds resulting from erosion that eventually translates into sedimentation in lowlands depends on natural fluctuations in climate and anthropic influence. In what relates the latter, periods of population growth reflect in development of agriculture, deforestation and consequently more sediment availability to the coastal areas, particularly obvious in sheltered locations as estuaries and lagoons (e.g. Dabrio et al., 2000; Komar et al., 2004). In contrast, periods of demographic recession relate with forest expansion and regain of natural vegetation. We present an upgrade of previously published similar approaches on the studied lagoons, namely those by Freitas (1989), Freitas et al. (1992), Henriques (1992) and Henriques et al. (2002). 


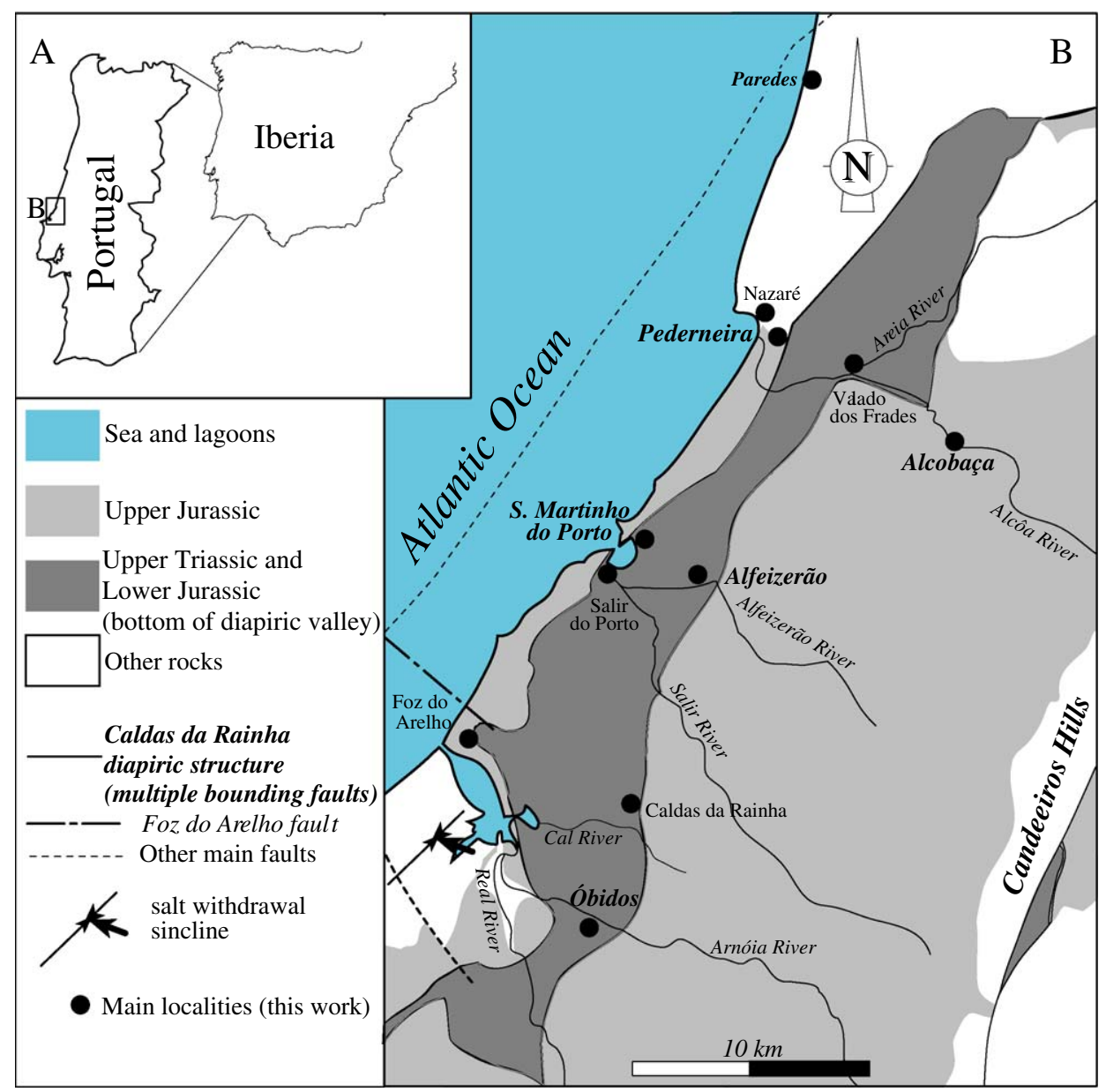

Fig. 1. The studied region, focused in the Caldas da Rainha diapir valley. A: Location. B: Main structural features and synthetic geology.

\section{Regional settings}

\subsection{Geology and geomorphology}

The Caldas da Rainha valley is a flat-floored elongated depression extending for $40 \mathrm{~km}$ between Nazaré and Óbidos (Fig. 1) controlled by the Pombal-Santa Cruz fault system. This system was active with transtensional movement essentially during the Late Jurassic/Early Cretaceous and acted as a reverse fault during the Late Miocene Betic transpression phase (Canérot et al., 1995). Both phases included major movement of Triassic/Lower Jurassic mobile evaporites, marls and mudstones (Dagorda Formation) which detached from the rigid basement to form structure-controlled diapiric domes elongated NNESSW. Further erosion of the cap rock excavated the abovementioned valley which is limited by steep-sloped scarps cut in Upper Jurassic limestone and siliciclastic rocks (Fig. 2). Throughout the Cenozoic a thin cover of detrital sediment accumulated upon the plastic diapiric nuclei and levelled the valley floor. A synthesis of the regional geology and aspects of the human insertion in the landscape is presented in Dinis and Bernardes (2004).
The Caldas da Rainha valley lays close to the shore from which is separated by the hills built in raised Mesozoic rocks forming the western border of the diapir (Fig. 1). A number of NW-SE faults cut these rocky elevations and cross through the diapiric structure; close to the sea they promote localized erosion of the resistant ridges and the establishment of paths that have been exploited by streams to outlet in the ocean-Alcôa River and drainage channels of the S. Martinho do Porto and Óbidos watersheds. The location of the Óbidos lagoon is also controlled by surface subsidence related with deep-seated salt withdrawal; its inlet is located in a fault or in the boundary between the cemented and relatively rigid Upper Jurassic sandstones and the loose and less resistant Lower Cretaceous clastic rocks.

\subsection{The coast}

Between Nazaré and Óbidos the coast is essentially Primary according to Shepard (1963) in the sense the sea came to rest against a landform essentially shaped by diastrophic (tectonic) causes; these left an imprint in the regional trend, linearity and smoothness of the coast in this 


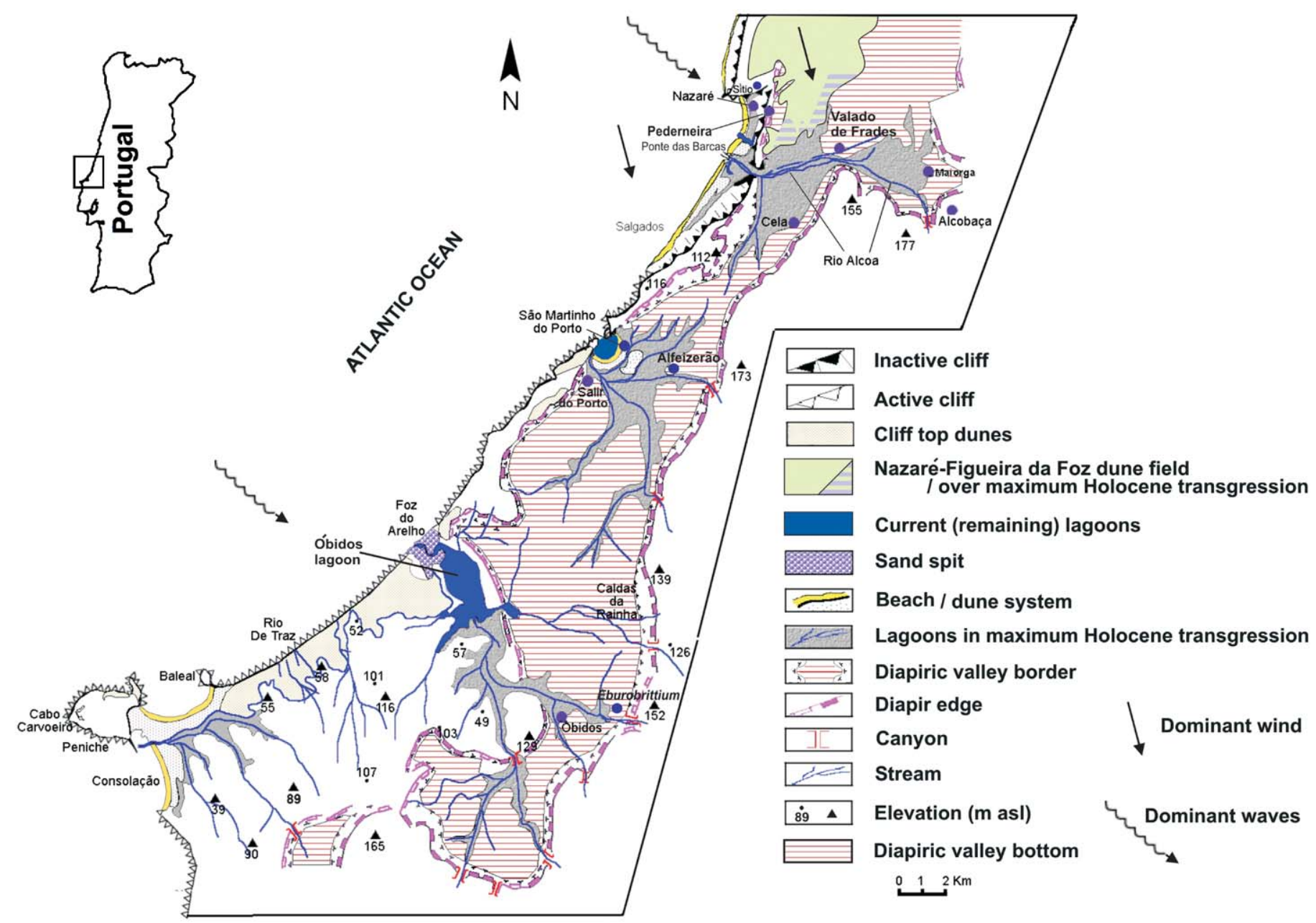

Fig. 2. Geomorphological map of the coastal area between Nazaré and Peniche, including the Caldas da Rainha diapir valley (m asl—metres above sea level).

section. Secondary reworking by marine agents shaped a detached beach-dune system between Nazaré and Salgados and cut scarped cliffs further south (Fig. 2). The continuity of the coastline is interrupted by the outlet of the Alcôa stream (at present stabilized by the Nazaré harbor) and the lagoons of São Martinho do Porto and Óbidos (Fig. 2).

Tides are semidiurnal, the spring tidal range averaging $2.9 \mathrm{~m}$ (high-mesotidal coast, according to the modified classification of Hayes, 1979). This high energy, swelldominated stretch of coast is fully exposed to waves generated far in the Atlantic. The yearly modal wave height and period range between $1.5-3 \mathrm{~m}$ and $9-14 \mathrm{~s}$ off shore the northwestern coast corresponding with WNW to NNW swell generated in high latitudes in the North Atlantic, and prevails more than 3/4 of the year (Carvalho and Barceló, 1966; Costa, 1994). The shore wave regime is somewhat reduced in height due to early breaking (cf. Carvalho and Barceló, 1966) significant wave height $(\mathrm{Hs})$ being of approximately $2 \mathrm{~m}$ in the study area. Storms are frequent between October and March and typically raise 6-9 m-high waves along this coast (Pita and Santos, 1989, 1992;
Carvalho and Capitão, 1991). Westerly storms approach from W $(>50 \%)$ to WNW (circa 30\%) and last for 8-10 days, being extremely damaging and affecting the whole of the western coast. Southwesterly storms are usually short lived, and correspond to proximal source-areas, which typically raise $4-7 \mathrm{~m}$ high waves with $9-10 \mathrm{~s}$ period.

The wave climate generates intense southward longshore drift north of Nazaré, where the coast develops $\mathrm{N} 12^{\circ} \mathrm{E}$; between Nazare and Peniche the general trend of the coast rotates clockwise standing nearly perpendicular to the prevailing swell and therefore decreasing the littoral drift by two orders of magnitude. Sediment bypassing the Nazaré promontory is captured by, and mostly lost into, the Nazaré canyon whose head nibbles the coast (Duarte et al., 2000); sediment supply to this coastal stretch is, therefore, local and sourced by erosion of Upper Jurassic and Lower Cretaceous detrital rocks.

The Holocene transgression formed three vast lagoonal systems by drowning the depressions created by the diapiric activity of the Caldas da Rainha structure, named as Óbidos, Alfeizerão and Pederneira (Fig. 2). The establishment of detrital barriers (Obidos and Pederneira), 
determined by the deceleration of the sea-level rise rate in the Middle Holocene and the existing narrow inlets in rocky basement (Pederneira and Alfeizerão) provided sheltering to these lagoons which intensively silted up, especially after the Christian reconquest (end of the 12th century); their shoaling and wet surface reduction appears to have followed an evolutionary pattern similar to other small coastal lagoons of the Portuguese coast (Freitas, 1989; Freitas and Andrade, 1998; Bao et al., 1999; Freitas et al., 2002b, 2003a; Blot, 2003). Currently, the S. Martinho do Porto lagoon is a relict of the former Alfeizerão lagoon and the Pederneira one is fully silted.

In this paper, fundamental aspects of morphological evolution since the Middle Holocene of the aforementioned lowlands are presented and discussed. Such synthesis constitutes a step previous to the required multi-proxy analysis of the infilling material by coring and geophysical methods, helpful in the planning of those tasks, as well as in the interpretation of its forecoming data.

\section{Methods and data sources}

The proposed landward boundaries of the drowned lowlands within the Caldas da Rainha valley, contemporaneous of the Holocene transgression maximum (Fig. 2), are based in field and geomorphologic analysis of the currently infilled alluvial plains, using topographic (Army Cartographic Survey, 1/25000) and geologic (Portuguese Geological Survey, 1/50 000) maps. Their subsequent evolution was evaluated using the location of archaeological to historical coastal vestiges and relied also upon the interpretation of documentary information - e.g. maps and text accounts. Before the first charts in the 16th century, archaeological and written sources are the main source of information, with relevance to the record of activities related with the harbours within the lagoons from the 11 th to the 16 th century. Maps from the 16th century onwards were studied, but they allow high accuracy only since the middle 19 th century.

To evaluate human impact and natural (essentially climatic) forcing on the silting, we considered the historical data at the Iberian and regional (drainage basin) scales, as well as temperature-inferred data to the north-western Iberia, in the context of larger-scale global trends of temperature and solar activity (Eddy, 1988; Stuiver et al., 1998; Mann et al., 1999; Solanki et al., 2004). The Holocene climate of north-western Iberia, presumably similar to the prevailing in the focused area, was recently characterised by Martínez-Cortizas et al. (1999) which studied mercury accumulation, and by Desprat et al. (2003) using pollen data. These works recognised the First Cold Subatlantic/Neoglacial Period, the Roman Warm Period, the Dark Ages cold period, the Medieval Warm Period, the Little Ice Age and the recent warming (20th century). A synthesis of the following main periods, events and interpretations is presented in Table 1 .

\section{The Holocene transgression}

During the last $18 \mathrm{ky}$ major changes in global climate and in sea-level occurred, driving significant transformations in the landscape in the middle latitudes of the Northern Hemisphere, where the Portuguese coast, in general, and the study area, in particular, are included (see Freitas et al., 2003b, for details). There is general agreement in dating the Last Glacial Maximum of circa 18000 BP (Bell and Walker, 1994) and despite some variability in the figures reported for the contemporaneous low-stand, $120 \mathrm{~m}$ below present-level may be taken as a reasonable or minimum estimate in both margins of the North Atlantic (Jelgersma and Tooley, 1995). Since then climate changed in general towards amelioration, this pattern having been disturbed by the short-lived cooler episodes of the Older and Younger Dryas. Sea-level and rates of sea-level change varied in tune with climate fluctuations during the last $18 \mathrm{ky}$ and two distinct periods can be recognized: an earlier period, from 18 to $6 \mathrm{ka}$, of rapid sea-level rise, during which the present-day rate of change has been exceeded by at least a factor of ten though, in places, the Younger Dryas is marked by a temporary reversal of this trend; the period from $6 \mathrm{ka}$ to the present, when sea-level rise decelerated and local and regional processes (isostasy, subsidence, sediment supply, anthropic activity) became pre-eminent (Bao et al., 1999; Freitas et al., 2003b).

Studies on the Portuguese coast and shelf (cf. Dias, 1987; Rodrigues et al., 1991) suggest that sea-level followed a similar pattern in general terms (Freitas et al., 2003b). The major features shown in their model since the Late Glacial include: an episode of rapid sea-level rise that attained circa $-40 \mathrm{~m}$ at the end of the Bölling-Allerød Interstadial; a sealevel fall to circa $-60 \mathrm{~m}$ at the end of the Younger Dryas Stadial, followed by a second period of rapid rise in sealevel which reached circa $-20 \mathrm{~m}$ between $9000-8000 \mathrm{BP}$. Due to the high rate of rise in base level, deposition was unable to cope with drowning and the resulting retreating coastline contour should be very irregular. Since then, the rate of sea-level rise decreased, the present-day level being attained after $5000 \mathrm{BP}$.

From the 1990s onwards the study of SW Portuguese lowlands yielded information on their palaeoenvironmental evolution and sea-level fluctuations throughout the last 14 ky (e.g. Queiroz and Mateus, 1994; Bao et al., 1999; Cruces et al., 1999; Freitas et al., 1999, 2002a, b, 2003a, b; Cearreta et al., 2003; Santos and Goñi, 2003) and similar work has been recently initiated in the NW estuaries (e.g. Drago et al., 2002). The sedimentary record of these lowlands keeps a signature of the afore-mentioned two contrasting periods of sea-level rise: before $6000-5000 \mathrm{BP}$ sedimentation has been essentially controlled by globalscale forcing with emphasis to sea-level, while after $6000-5000 \mathrm{BP}$, in consequence of deceleration of sea-level rise rate, the local forcing factors overwhelmed the global ones. 
Table 1

Synthesis of the main periods, events and interpretations (Ct.- century)

\begin{tabular}{lll}
\hline Chronology & Period & Political and social history \\
\hline c. 5000 BP & $\begin{array}{l}\text { Late Holocene } \\
\text { transgressive maximum/ } \\
\text { Celtic Period } \\
\text { Roman conquest and } \\
\text { dominance }\end{array}$ & $\begin{array}{l}\text { Palaeolithic (very rare), } \\
\text { Neolithic and Celtic } \\
\text { settlements } \\
\text { Marginal importance in } \\
\text { the Lusitania Province; }\end{array}$ \\
Early 5th Ct. AD & $\begin{array}{l}\text { Barbarian Invasion (Sueve } \\
\text { and Visigothic kingdoms); }\end{array}$ & $\begin{array}{l}\text { Ethnical and religious } \\
\text { fights; embattled frontier; }\end{array}$ \\
& $\begin{array}{l}\text { Muslims invasion (711-714 } \\
\text { AD) and dominance; } \\
\text { Christian progression }\end{array}$ & Earlamities \\
1140 AD & Eeconquest & Muslims raids (almohads) \\
1195 AD & $\begin{array}{l}\text { Internal organisation of } \\
\text { the Kingdom of Portugal }\end{array}$ & $\begin{array}{l}\text { Intense commercial and } \\
\text { naval activities in the } \\
\text { lagoons }\end{array}$
\end{tabular}

Early 14th Ct. AD Late Medieval

Mid 15th Ct. AD Discoveries Era

Late 16th Ct. AD Modern Age

Early 19 th Ct. Constitutional Monarchy

Early 20th Ct.

Late 20th Ct. (c. 1970)
Contemporary Age plagues; Black Death (1348); internal and Iberian wars

National policy: naval trade and overseas exploration

Decline of Portugal as overseas power; Spanish domination (1580-1640); independence war (1640-1668); 1755 earthquake and tsunami

Regional agrarian economy; Napoleonic invasions (1807-1812); independence of Brazil (1822); civil war (1820-1833); extinction of the religious orders (1834) Regional agrarian Republican Regime: 1st Republic (1910-1926) and Dictatorship (1926-1974) economy; World War I and the Spanish flue (1917-1919); large-scale emigration (Europe and Overseas)

Rules for sustainable

Democracy, European
Successive famines and Silting/evolution (1822-1910) regional development
Cold interval within the late Medieval Warm Period (Wolf Solar Minimum: 1305-1345) and Pederneira lagoons); early Little Ice Age (Spörer decrease in sediment Minimum after 1418) Little Ice Age; small increase in temperature and solar activity after c. 1500 follows the late Spörer Minimum (end in 1540)

Little Ice Age (including the Maunder Minimum: 1640-1715)

Little Ice Age (including the Dalton Minimum: 1795-1825)

Demographic stagnation: fishing in the Óbidos lagoon and shipyard in S.Martinho do Porto

Demographic collapse; reduced farming (less in the Alfeizerão and supply to the coast Demographic grow; intense deforestation; increased farming; seaward decline in navigability

Demographic stagnation; seaward relocation of harbours
Very sparse population; dense vegetation cover

Minor deforestation and increase in farming; Eburorittium harbour Low demographic density; Very small reduction of reduced farming

Establishment of the Cistercian Abbey of Alcobaça in 1153 Demographic grow; the Óbidos lagoon); active salt-pans; longshore drift increase and dune-fields progradation relocation of harbours and

\section{Recent warming; very
solar activity (since c. 1935)} Union (since 1986)
Little evolution; maintenance of maximum transgression shores Infill of some tributaries mouths immersed areas

Very small reduction of immersed areas

Most of embayments in the Óbidos lagoon)

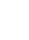

\section{Expansion of natural} vegetation on the drainage basins; reduced silting rate of the lagoons

Fast infill; frequent inlet closure

(1)

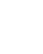

Constant rate of infill; complete infill of the Pederneira lagoon; Alfeizerão lagoon achieves present configuration; c. $1 \mathrm{~km}$ seaward shift of Óbidos lagoon inner limit Óbidos lagoon: inlet closure and freshwater influence increase, high rate of infill; minor infill of the S.Martinho lagoon

Recent warming; very high Drainage basins and solar activity coastal planning of alluvial infill rate,
Small sea-level rise; strong Óbidos lagoon: constant decrease in sediment rate of infill, dredging and supply to the coast, leading progradation of marine to erosion clastics; minor infill and dredging of the S.Martinho lagoon Óbidos lagoon: reduction dredging and marine clastics progradation; reduction of S.Martinho lagoon infill rate
Between Nazaré and Óbidos the Holocene transgressive maximum defined a flooding perimeter that roughly matches the landward edge of present-day alluvial deposits standing at 7-10 m elevation (Fig. 3) and usually marked by a conspicuous slope break (Henriques et al., 2002). This is to a large extent a morphological inheritance of a 


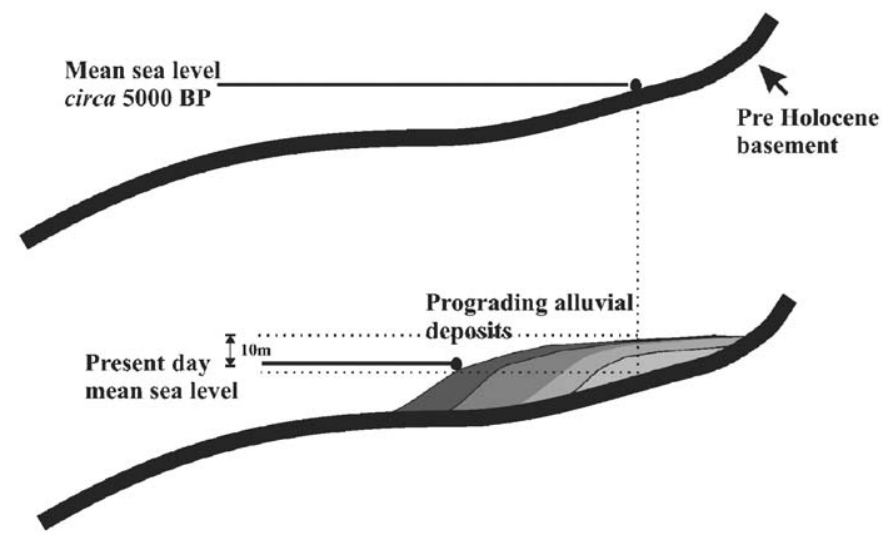

Fig. 3. Schematic diagram representing the Holocene maximum flooding (upper figure) and its relation with the present day $10 \mathrm{~m}$ topographic level (lower figure). During the Holocene alluvial deposits prograded and filled the edge of the lagoon raising the surface above the present base level. The slope cut in pre Holocene basement allowed the $10 \mathrm{~m}$ contour to roughly mirror the maximum extent of the Holocene transgression.

previous surface deeply dissected by streams during Last Pleistocene low-stand that has been rapidly drowned by the Holocene transgression. The horizontal distance between the landward edge of alluvium and the $10 \mathrm{~m}$ contour is in general small given the slope break, and this line may be taken as a landward boundary to the flooded surface, which corresponds to a vast area extending inland. It should be noted that this does not correspond to a higher than present Holocene sea-level stand (Fig. 3). Since circa 5500-5000 BP onwards the wetlands evolved until present as coastal lagoons, due to the establishment of detrital barriers favoured by sea-level rise deceleration.

\section{Late Holocene environmental changes and infill}

\subsection{Evolution previous to the Christian reconquest}

After the Younger Dryas, oak (Quercus) forests dominated the north and central part of western Iberia, as revealed by the marine near-shore pollen record (Hooghiemstra et al., 1992; Desprat et al., 2003; Turon et al., 2003). Vegetation will remain essentially unchanged and added in the studied area by chestnuts (Castanea) and pines (Pinus) till the Middle Ages (Gonçalves, 1989).

The lagoons constituted marine to brackish environments loci of high productivity but few isolated findings can be attributed to the Palaeolithic in their drainage area. However, the region (Estremadura), and the studied area in particular, records a large increase in settlements since the Early Neolithic (Zilhão, 2000). The increase in coastal progradation rates around $2500 \mathrm{BP}$ recorded in several estuaries around the Mediterranean-Atlantic connection (Dabrio et al., 2000) was not recognized in the area so far. Archaeological remains extending from the Neolithic to Roman times are abundant in the study area and concentrate along the proposed shore in the maximal extension of the lagoons, especially in the innermost locations (Barbosa, 1987; Henriques et al., 2002; Moreira, 2002). During the Roman period the region under study was not important in the context of the province of Lusitania in terms of mineral and agricultural resources. However, several villae and farms were found, the most noteworthy finding being the recent (1994) location of the civitas of Eburobrittium, referred by Pliny the Elder (1st Century AD, Naturalis Historiae, Book IV, Chapter 4), an important harbour for regional trade from the end of the 1 st century BC to the 2nd half of the 5th century AD (Moreira, 2002; Blot, 2003; Fig. 2). A previous Celtic settlement probably existed very close, as revealed by the toponomy, considering the Eburo component (Moreira, 2002) and admitting that Óbidos is an evolution after oppidum, the Latin word for a large pre-Roman town, frequently a fortress or locality in a high place (Fig. 2). Located about $1 \mathrm{~km}$ east of Óbidos in a thermal area over the diapir border, it depended and benefited from favourable conditions offered by the lagoon. Until the Roman occupation, the development of agriculture was restricted but the Romanization implied major changes in landscape, namely by a vast consumption of timber and the widespread use of the plough (Brown, 1995), that happened in a period of general increase of agriculture documented in western Iberia (Fabião, 1992), and most likely favoured by the Roman Warm Period (250 BC-AD 450). An increase in continental erosion by those times was inferred by the progradational infill of the nearby Sizandro River valley $(30 \mathrm{~km}$ south of the Óbidos lagoon basin; Hoffman, 1989). On the other hand, the spatial overlapping of Neolithic and Roman remains (Alarcão, 1990; Barbosa, 1992; Moreira, 2002), and the written data suggest that little changes occurred in the extension of the flooded surface between the Holocene transgressive maximum and circa $1500 \mathrm{BP}$, in spite of a relatively stable base level. In agreement, the eventual infill of the studied lagoons was with high probability expressed by the vertical accumulation and/or progradation restricted to the stream's mouths.

Later, in the beginning of the 5th century, the central west Iberia was exposed to the barbarian invasion of Vandals, Sueves and Visigoths and a permanent state of war in the study area, which stood at the border between Sueve and the Visigoth kingdoms, persisted until the last quarter of the 6th century. The coeval configuration of the coastal lagoons can be established based on the location of the archaeological remains of several watch towers from the Visigothic Era, built along the margins of Pederneira and Alfeizerão lagoons either to protect local harbours or as lighthouses for internal navigation (Natividade, 1960; Garcia, 1970; Barbosa, 1992), suggesting a small reduction of the immersed area in comparison with the transgressive maximum.

To the political and social instability of the late Roman Period and the barbarian kingdoms natural calamities can be added, such as famine, bad crops, plagues and even 
grasshopper invasions, recorded in seven periods between AD 578 and 711 (Mattoso, 1992a). Shortly after, between AD 711 and 714, the Maghribin forces leaded by Tarik subjected Iberia initiating a period of Muslim occupation that came to an end only in the mid 12th century. The cold phase attributed to the solar minimum around AD 660-740 (Stuiver et al., 1998) most certainly played a role in this period of crisis.

During the 8th and 9th centuries, the Islamic control changed the land use in southern Iberia, but it had low impact north of the Tagus, including the study area, which remained sparsely populated (Torres, 1992). The coast of the area was under the Norman (Vikings) raids threat (till the 11th century; Coelho, 1989), and Alfeizerão (an Arabic toponym) and Óbidos were the main localities (Barbosa, 1992). The so-called reconquista (reconquest) of Iberia from the Moors progressed southward from the Asturias region. Once the fertile lands of northern Portugal reached political stability under Christian rule, during the 10th century, the Minho and Douro basins increased the sediment nourishment to the coast (Abecassis, 1955).

Again, the studied region became an embattled frontier between the northern Christian kingdoms (initially the Kingdom of León and later the Kingdom of Portugal) and the Muslim states, and many raids from both belligerents crossed the region during the 10th to the 12th centuries (Barbosa, 1992; Macías, 1992).

The first King of Portugal (Afonso Henriques) defeated the Muslim armies in several battles in central Portugal (from Coimbra to Lisbon) and donated in 1153 a vast domain of the drainage area of the Pederneira and S. Martinho do Porto-Alfeizerão lagoons for the establishment of a Cistercian Abbey in Alcobaça (currently a UNESCO Cultural World Heritage). The vows in the Cistercian Order encouraged their settlement in areas lacking structured human occupation and the monks were highly skilled farmers using the most advanced hydraulic technology available in those times. However, the area achieved military and social stability only in 1195, date of the last Almohad (Muslim) raid affecting the Abbey (Barbosa, 1992; Mattoso, 1992b).

In conclusion (Table 1), from the Holocene transgressive maximum (around $5000 \mathrm{BP}$ ) to the end of the 12th century $\mathrm{AD}$, the drainage area of the studied lagoons kept a very low demographic density and a dense vegetation cover, experiencing the lagoons, thus, a slow evolution.

Anthropogenic impacts fit the time-windows of main climatic episodes, suggesting a feed-back effect. We deduce that after the stillness in the cold period before $250 \mathrm{BC}$, somewhat greater morphological changes took place in the lagoons during the Roman Warm Period (politically from the late 1st century BC to the early 5th century AD). Modifications in morphology were reduced during both the cold Dark Ages (AD 450-950) and the Oort solar minimum (essentially the 11th century).

\subsection{Evolution from the Christian reconquest to the end of discoveries era}

The main morphosedimentary changes occurred in these wetlands were essentially due to anthropic activity following the Christian Reconquest (Table 1). During the Middle Ages the main anthropic impacts in the region were the result of the action of the Cistercian monks of Alcobaça as landowners of most of the Pederneira and Alfeizerão lagoons drainage basins. The Cistercian communities were organised and disciplined corporations using updated farming techniques, seeking the maximal productivity of a variety of possessions and the acquisition of additional lands and rights to support the abbey's growth. The following synthesis concerning the medieval evolution of those lagoons is largely based in the studies of the detailed written record of the abbey operations by Barbosa (1992) for the AD 1100-1325 period, and Gonçalves (1989) for the 14th and 15th centuries.

Under the exceptionally favourable weather constraints throughout the Medieval Climatic Optimum (Brown, 1995), in particular the Grand Solar Maximum (Stuiver et al., 1998), the 13th century was a period of demographic grow in Europe, also evident in Portugal (Mattoso, 1992c). The considered region witnessed new settlements by locals and immigrants and significant enlargement of farmland, largely reclaimed from forests (Coelho, 1997; Barbosa, 1992); swamps were drained, mainly by the Cistercian's labour and expertise. Furthermore, until the Industrial Revolution (in this region well into the 19th century) wood was the basic manufacture and building material, as well as fuel for domestic and industrial activities. The works of Devy-Vareta $(1985,1986)$ indicate that Portugal exported timber during the 12th century but this situation reversed towards importation in the next century, greatly increased in mid 15 th century, revealing the high consumption of this raw material. As developed bellow, this deforestation was intense in the studied region and led to erosion and the consequent contribution to the silting of the nearby lagoons. By the end of the 13th century, most of the embayments in the Alfeizerão and Pederneira lagoons changed to swamps or reclaimed areas, such as the Tornada plain and the Alcobaça channel. Nevertheless, documents from the 13th century AD describe an easy access by boat to the innermost recesses of Pederneira and Alfeizerão lagoons, used by the monks of the Alcobaça's abbey to maintain intense commercial and naval activity (Cocheril, 1978; Barbosa, 1992).

Following the southward progressing of the reconquest, intensive sediment release to the Portuguese coast was reflected in high rates of clastic input which accumulated by longshore drift to form the spit sheltering the Aveiro lagoon: this process initiated in the 10th century, but greatly increased in the 12th (Abecassis, 1955). One other expression of high sediment availability along the central Portuguese coast are the accretion and landward progradation of large dune fields. For example, the dune field 
north of the Pederneira lagoon was partially covered by a pine-tree forest since the Neolithic (Devy-Vareta, 1985), most certainly dense in the 12th century, but that had to be expanded in the late 12th and 13th centuries (King Dinis) as countermeasure to prevent disruption of agriculture by invading aeolian sands (Barbosa, 1992). By then, the southern margin of the dune field became almost stable.

The Óbidos lagoon drainage area was less affected by anthropic activities in the Middle Ages, essentially because it was in large part a domain of the Crown and the town of Óbidos a municipality owned by the King and, later, the Queen. The inner branches of the lagoon reached Óbidos by that time (Moreira, 2002). If by one hand during the 13th century the Alcobaça Abbey experiences a considerable increase in the number and area of benefactions in this sector and new settlings accommodate immigrants from north-western Iberia and France (Barbosa, 1992), on the other hand, the royal domain was largely a hunting reserve that contributed to the preservation of most of the forest until the end of the 14th century (Devy-Vareta, 1985).

The 13th century was a turning point toward cooler conditions and by its end land use was clearly unsustainable, due to overexploitation by farming and deforestation. Such situation triggered a regional demographic decline, and even the expansion of the Alcobaça Abbey stagnated (Barbosa, 1992; Mattoso, 1992c). In the first half of the 14th century, several bad crops and the Black Death (plague), particularly in 1348, and several internal wars produced a crisis in the agricultural landscape as the population was severely reduced (up to $50 \%$ in all Portugal; Coelho, 1997; Sousa, 1992). Consequently, in all western Iberia many cultivated lands were regained by the natural vegetation (Desprat et al., 2003), reducing the rhythm of silting of estuaries and lagoons and inducing a decrease in sediment supply to the coast, marked by the delay in the accretion rate of growing spits in the Portuguese shore (Dias et al., 2000). Probably linked with the Wolf Solar Minimum and the early Little Ice Age (Stuiver et al., 1998; Desprat et al., 2003), the successive famines coupled with wars (both civil and with Castilla) recorded in Portugal during the 2nd half of the 14th century and first half of the 15th century were responsible for a demographic stagnation (Sousa, 1992).

Despite the continental-scale crisis of the 14th century $\mathrm{AD}$, coeval documents record for the first time navigability problems in these lagoons resulting from silting up. This may indicate a local reduction to the general trend of disruption of agriculture in the study area favoured by both natural and social causes; the former derive from the relatively small dimension of the watersheds draining into the Caldas da Rainha depression and the latter with an island-effect associated with the vast domains of the Cistercian Abbey of Alcobaça, where agriculture suffered a minor decline (Gonçalves, 1989). On the other hand, harbour activities diminished along this century also due to the establishment of new anchorage places in the nearby open coast, like Paredes (about $10 \mathrm{~km}$ north of Nazaré, had "foral", a royal settling chart, in 1286; Gonçalves, 1989) and to the emergence of the Peniche fishing community (Fig. 2; Blot, 2003), following the fading of raids from Muslim pirates after the conquest of the Algarve region in the mid 13th century (Guerreiro, 1996; Mattoso, 1997).

In the beginning of 15 th century the forest was depleted, but the nation's economy and political efforts drove to the naval trade and exploration of new lands as suppliers and markets, a change well recorded in the studied area (Table 1). Such effort required a large amount of vessels and a new impulse of deforestation started (Sousa, 1992). The 2nd half of the 15th century recorded a demographic grow (Sousa, 1992), of exceptional dimension in the studied area: between the end of the 14th century and 1537 the population almost doubled, reflected in expansion of farmed land (Gonçalves, 1989). In this period the inner harbours declined very fast and had to be relocated seaward to the inlets vicinity (e.g. from Pederneira or Valado to Ponte das Barcas and from Alfeizerão to Salir do Porto; Fig. 2). Further upstream, the main tributaries and sheltered recesses changed into salt marshes or swamps in rapid vertical accretion (Henriques, 1996). The earliest documentary account of an inlet closure due to the formation of a sand bar dates from the late 14th century (1377, a report of the Alcobaça Monastery), and similar reports become frequent since the middle of the following century (Natividade, 1960; Gonçalves, 1989).

Between the 16th and 17th centuries, the lagoons silting rate increased, the wet surface experienced substantial reduction and the largest vessels could hardly navigate, as deduced from the documentary record, essentially due to deforestation for agriculture, naval construction and fuel: at that time the pine forest north of Pederneira had suffered many cuts to supply the Pederneira and Alfeizerão shipyards (Natividade, 1960; Gonçalves, 1989). The problem was so dramatic all over the country that laws were published (in 1495 and 1565) in order to increase private and public efforts for the expansion of timberland (Devy-Vareta, 1986). Salterns and intense harbour activities were still associated to Alfeizerão in the 1st quarter of the 16th century (accommodating up to 80 vessels; Gonçalves, 1989), and shipyards were operative till the 17 th century, but most probably such nautical facilities were successively relocated westward apart from the main locality.

In all three lagoons, the inlet narrowing or even closure, coupled with intertidal accumulation, led to the reduction of the tidal prisms and a feedback effect reinforced the silting trend and the barrier system. In the turn of the 16th century sailing within the Pederneira lagoon was very difficult (Gonçalves, 1989) and a new fisherman settling was established in Nazaré (Costa, 1712). The shallow water quickly transformed into marsh and swampland that have been extensively artificially drained and stabilised.

The Óbidos lagoon surface reduced to a third of its maximum dimension since the 14 th century. It is noteworthy that between the end of the 14th and beginning of 
the 17th centuries almost half of the royal hunting reserves around this lagoon changed to a regular forest regime, exposed to agriculture and cutting pressures and in 1474 the King allowed the cut of timber in the domains of abbeys (Devy-Vareta, 1986). Furthermore, the earliest documentary record accounting for the need of frequent barrier breaching and forcing its artificial opening dates from the end of the 14th century (Freitas, 1989; Trindade, 2001). However, it looks that relatively large ships were built in the lagoon in the early 16th century (Gorjão, 1999).

The Discoveries Era ended around 1580, due to the emergence of other countries as naval overseas powers (mainly Britain and Netherlands), and to the junction of Portugal with the Spanish crown following the defeat of Portuguese Army and the death of King Sebastião I in the battle of Alcazar El-Kibir. A period of decay will follow until the 18 th century.

\subsection{Evolution from the 17 th century to the present}

The role of the studied lagoons in nautical enterprises ended by silting coupled with the decline of overseas Portuguese power, coeval with a long-term demographic stability (Serrão, 1993). A significant role in this evolution can be attributed to the successive social national crisis (Table 1), such as the Spanish domination (1580-1640), the independence war (1640-1668), the 1755 earthquake and tsunami (Sousa, 1932), the Napoleonic invasions (1807-1812), the independence of Brazil (the main economic source, in 1822), the civil war between liberals and conservatives (1820-1833), the extinction of the religious regular orders (1834), World War I and the Spanish flue (1917-1919), the political chaotic late monarchic and 1st Republic periods (1850-1926), the dictatorship regime (1926-1974), and the large-scale emigration (Europe and Overseas, since the early 20th century to the 1980s). Among those, the 1755 earthquake, the Napoleonic invasions and the extinction of the religious orders (including the Cistercian) had particularly intense impact in the region.

Despite the technical stagnation (Vaquinhas and Neto, 1993; Serrão, 2004), the agricultural character of the studied region, that remains till our days, and the climate in the Little Ice Age were not favourable to the recovery of the vegetation cover. The main political changes in Portugal during this period (Independence restoration in 1640, Liberal Revolution in the 1830s and the Republican Regime started in 1910) did not change much the land use of the region. Under these circumstances, we can presume a regular decrease of lagoonal volume during the 17th-19th centuries (Table 1).

By the end of the 18th century vast lagoonal surfaces were replaced by alluvial plains. The harbour of Pederneira was definitely abandoned and the loss of navigability conditions of the Salir harbour compelled the transfer of related activities and facilities to $\mathrm{S}$. Martinho do Porto where it remained until the beginning of the 20th century. By the end of the 18th century the Pederneira lagoon recorded some navigation (Garcia, 1970) and probably an active shipyard (Blot, 2003), but it was completely infilled in the beginning of the $1800 \mathrm{~s}$, as mapped in Loureiro (1905). The Alfeizerão lagoon had already acquired the present-day configuration, most probably in the early 18th century (Costa, 1712).

From the end of the 16th to mid 18th centuries, the limit between the Óbidos lagoon and the upstream swampy valleys should have shifted from about $3.5-2.5 \mathrm{~km}$ south of its current location (Henriques, 1992; Trindade, 2001). The comparison of successive maps from 1867 to the present shows a reduction of the lagoonal surface, essentially in both inner branches, with an average annual sedimentation rate of $1.2 \mathrm{~cm} /$ year between 1917 and 1980 (Freitas, 1989). Empirical quantification of soil loss in the watershed yields potential accumulation rates in the range $0.5-2.4 \mathrm{~cm} /$ year (Cruces, 2001).

The global warming marks the 20th century. Yet, any possible contribution to reducing the erosion was largely overstepped by the improvement of farming techniques, as well as a great increase in the population of the region, surely reflected in a growth of the infill rate in the investigated area, mitigated in the last three decades by a more sustainable regional planning and, essentially, dredging and sand mining.

\section{Conclusions}

The studied-case shows drastic environmental changes both natural and anthropogenic, synthesized in Table 1 . The changes were extremely fast in a geological perspective, but, overall, the change in morphology, sedimentary systems dynamics and distribution, and ecology overstepped the adaptational capability of the regional society, triggering or contributing to social crises.

The main identified morphosedimentary changes occurred in these wetlands are, essentially, due to anthropic forcing following the Christian Reconquest. In fact, from a physiographic unit that attracted prehistoric settlers, during the Middle Ages and Renaissance the lagoons became a locus of important nautical and fishing activities, and their drainage basins were intensely used for agriculture. Later, due to severe infill, sailing turned out to be almost impossible and most of the area drowned in the maximum sea level was claimed to farming. In synthesis, we conclude that, the human activities, influenced by the historical small climatic oscillations, greatly accelerated the natural silting trend of the lagoons during the last millennium.

Even if it is impossible to reverse such impacts, they should be included in future human activities as costs and considered for prevention. Moreover, the knowledge of this chain of processes can contribute to establish a clear cultural shift to the coming generations towards a better interaction between human society and Earth's natural systems. 


\section{References}

Abecassis, C., 1955. The history of a tidal lagoon inlet and its improvement (the case of Aveiro, Portugal). In: Proceedings of the Fifth Conference on Coastal Engineering, Grenoble, pp. 329-363.

Alarcão, J., 1990. O reordenamento territorial. In: Serrão, J., Marques, A.O. (Eds.), Nova História de Portugal 1. Editorial Presença, Lisbon, pp. 352-382.

Bao, R., Freitas, M.C., Andrade, C., 1999. Separating eustatic from local environmental effects: a Late Holocene record of coastal change in Albufeira Lagoon, Portugal. The Holocene 9, 341-352.

Barbosa, P.G., 1987. O plano arqueológico de Alcobaça. Novas Perspectivas. In: Da Pré-História à História. Homenagem a Octávio da Veiga Ferreira. Editorial Delta, Lisbon, pp. 321-328.

Barbosa, P.G., 1992. Povoamento e estrutura Agrícola na Estremadura Central (Sec. XII a 1325). Instituto Nacional de Investigação Científica, Lisbon, 397p.

Bell, M., Walker, M., 1994. Late Quaternary Environmental Change. Physical \& Human Perpectives. Longman Scientific \& Technical, 273p.

Blot, M.L.P., 2003. Os portos na origem dos centros urbanos. Contributo para a arqueologia das cidades marítimas e flúvio-marítimas em Portugal. Instituto Português de Arqueologia, Trabalhos de Arqueologia 28, Lisbon, 338p.

Brown, N., 1995. The impact of climate change. Some indications from History, 250-1250 AD. OCEES Research Paper, Oxford, 16p.

Canérot, J., Rey, J., Batista, R., Manuppella, G., Peybernès, B., 1995. Nouvelle interprétation structurale et géodynamique de la marge atlantique portugaise dans le secteur de Caldas da Rainha (Portugal). Comptes Rendus de l'Academie des Sciences, Série IIa 320, 523-530.

Carvalho, J.R., Barceló, J., 1966. Agitação marítima na costa Oeste de Portugal Metropolitano-Contribuição para o seu estudo, Vol. 290. Memórias do Laboratório Nacional de Engenharia Civil, Lisbon 34p.

Carvalho, M., Capitão, R., 1991. Valores Extremos da Agitação Marítima na Costa Oeste de Portugal. Recursos Hídricos 12(4), 33-42.

Cearreta, A., Cachão, M., Cabral, M.C., Bao, R., Ramalho, M.J., 2003. Lateglacial and Holocene environmental changes in Portuguese coastal lagoons: 2. Reconstruction of the Santo Andre coastal area (SW Portugal) during the last 14000 years based on microfossil multiproxy evidence. The Holocene 13, 447-458.

Cocheril, M., 1978. Routier des Abbayes Cisterciennes du Portugal. Fundaç ão Calouste Gulbenkian - Centro Cultural Português, Paris 487p.

Coelho, A.B., 1989. Portugal na Espanha árabe. Editorial Presença, Lisbon.

Coelho, M.H.C., 1997. O Baixo Mondego-um pouco de história. Cadernos de Geografia 16, 55-68.

Costa, A.C., 1712. Chorographia portuguesa e descripçam topographica do famoso reyno de Portugal, Vol. 3. Oficina Real Deslandesiana, Lisbon, Portugal.

Costa, C., 1994. Wind Wave Climatology of the Portuguese Coast. Technical Report 6/94-A, Instituto Hidrográfico/Laboratório Nacional de Engenharia Civil, Lisbon, Portugal.

Cruces, A., 2001. Estudo a micro e meso-escala temporal de sistemas lagunares do SW Alentejano (Portugal): as lagunas de Melides e Santo André. Unpublished MSc Thesis, University Lisbon, 228p.

Cruces, A., Freitas, C., Andrade, C., 1999. Factores forçadores globais versus locais na evolução tardiglaciar e holocénica de sistemas lagunares do litoral SW português. Encontros de Geomorfologia, Universidade de Coimbra, pp. 105-113.

Dabrio, C.J., Zazo, C., Goy, J.L., Sierro, F.J., Borja, F., Lario, J.G., Flores, J.A., 2000. Depositional history of estuarine infill during the last postglacial transgression (Gulf of Cadiz, Southern Spain). Marine Geology 162, 381-404.

Desprat, S., Sanchez-Goñi, M.F., Loutre, M.-F., 2003. Revealing climatic variability of the last three millennia in northwestern Iberia using pollen influx data. Earth and Planetary Science Letters 213, 63-78.

Devy-Vareta, N., 1985. Para uma geografia histórica da floresta portuguêsa-As matas medievais e a "coutada velha" do Rei. Revista da Faculdade de Letras, Geografia, Porto I Série, I, pp. 47-67.
Devy-Vareta, N., 1986. Para uma geografia histórica da floresta portuguêsa-Do declínio das matas medievais à política florestal do Renascimento (Sec. XV e XVI). Revista da Faculdade de Letras, Geografia, Porto I Série, II, pp. 5-37.

Dias, J.M.A., 1987. Dinâmica sedimentar e evolução recente da plataforma continental Portuguesa setentrional. Unpublished Ph.D. Thesis, University of Lisbon, Lisbon, 384p.

Dias, J.M.A., Boski, T., Rodrigues, A., Magalhães, F., 2000. Coast line evolution in Portugal since the Last Glacial Maximum until present-a synthesis. Marine Geology 170, 177-186.

Dinis, J.L., Bernardes, C., 2004. Upper Jurassic outcrops along the Caldas da Rainha diapir, Portugal - a regional geoheritage overview. Rivista Italiana di Paleontologia e Stratigrafia 110, 407-415.

Drago, T., Naughton, F., Moreno, J., Rocha, F., Cachão, M., SanchezGoñi, M.F., Oliveira, A., Cascalho, J., Fatela, F., Freitas, C., Andrade, C., 2002. Geological record of environmental changes in the Douro estuary (NW Portugal), since the Late Glacial. In: Proceedings LITTORAL 2002, Eurocoast, III, pp. 341-346.

Duarte, J., Dias, J.A., Taborda, R., 2000. Cabeceira do Canhão da Nazaré: erosão versus sedimentação/Nazaré Canyon head: erosion versus sedimentation. Resumos $3^{\circ}$ Simpósio sobre a Margem Continental Ibérica Atlântica/Abstracts of Third Symposium on the Iberian Atlantic Margin, pp. 227-228.

Eddy, J.A., 1988. Variability of the present and ancient Sun: a test of solar uniformitarianism. In: Stephenson, F.T., Wolfendale, A.W. (Eds.), Secular Solar and Geomagnetic Variations in the Last 10,000 Years. Kluwer Academic, Dordrecht, pp. 1-23.

Fabião, C., 1992. O passado proto-histórico e romano-A romanização do actual território português. In: Mattoso, J. (Ed.), História de Portugal I-Antes de Portugal. Círculo de Leitores, Lisbon, pp. 203-299.

Freitas, M.C., 1989. A evolução da Lagoa de Óbidos nos tempos históricos. Geolis 3, 105-117.

Freitas, M.C., Andrade, C., 1998. Evolução do Litoral Português nos Últimos 5,000 Anos. Alguns Exemplos. Almadan 7, 64-70.

Freitas, M.C., Andrade, C., Jones, F., 1992. Recent evolution of Óbidos and Albufeira coastal lagoons. In: Proceedings of the International Coastal Congress, Kiel, pp. 167-186.

Freitas, M.C., Cruces, A., Andrade, C., 1999. As lagunas de Melides e Santo André: evolução e comportamento morfodinâmico. In: Proceedings "A zona costeira do Alentejo", Eurocoast Portugal, pp. 27-44.

Freitas, M.C., Andrade, C., Cruces, A., Amorim, A., Cearreta, A., Ramalho, M.J., 2002a. Coastal environmental changes at different time-scales: the case of the Melides barrier-lagoon system (SW Portugal). In: Proceedings LITTORAL 2002 III, Eurocoast, pp. 397-402.

Freitas, M.C., Andrade, C., Cruces, A., 2002b. The geological record of environmental changes in southwestern Portuguese coastal lagoons since the Late Glacial. Quaternary International 93-94, 161-170.

Freitas, M.C., Andrade, C., Rocha, F., Tassinari, C., Munhá, J.M., Cruces, A., Vidinha, J., Silva, C.M., 2003a. Lateglacial and Holocene environmental changes in Portuguese coastal lagoons: 1. The sedimentological and geochemical records of the Santo André coastal area (SW Portugal). The Holocene 13, 433-446.

Freitas, M.C., Andrade, C., Cruces, A., Cachão, M., 2003b. Sedimentary response to sea-level changes of Portuguese lowlands since the Late Glacial - a multidisciplinary approach. In: Proceedings, IX Congresso da Associação Brasileira de Estudos do Quaternário \& II Congresso do Quaternário dos Países de Língua Ibérica, Recife, Brazil, CD ROM, 5p.

Garcia, E.B., 1970. As torres e os fachos da Lagoa da Pederneira. Vestígios de navegações antigas na Lagoa da Pederneira. Arquivo de Beja 25-27, 65-76.

Gonçalves, I., 1989. O património do Mosteiro de Alcobaça nos séculos XIV e XV. Faculdade de Ciências Sociais e Humanas, Universidade Nova de Lisboa, Lisbon.

Gorjão, S., 1999. O Foral Manuelino de Óbidos. Câmara Municipal de Óbidos, Óbidos 79p. 
Guerreiro, L.R., 1996. O grande livro da pirataria e do corso. Círculo de Leitores, Lisbon 335p.

Hayes, M.O., 1979. Barrier island morphology as a function of tidal and wave regime. In: Leatherman, S. (Ed.), Barrier Islands. From the Gulf of St Lawrence to the Gulf of Mexico. Academic Press, New York, pp. $1-29$.

Henriques, M.V., 1992. Morphological evolution of the Óbidos Lagoon. Journal of Coastal Research 8, 677-687.

Henriques, M.V., 1996. A faixa litoral entre Nazaré e Peniche. Unidades geomorfológicas e dinâmica actual dos sistemas litorais. Unpublished Ph.D. Thesis, University of Évora, 575p.

Henriques, M.V., Freitas, M.C., Andrade, C., Cruces, A., 2002. Alterações morfológicas em ambientes litorais desde o último máximo transgressivo - exemplos da Estremadura e do Alentejo. Publicações da Associação Portuguesa de Geomorfólogos I, 99-109.

Hoffman, G., 1989. Estratigrafia holocénica da linha de costa nos vales dos rios Sizandro (Portugal) e Guadiana (Portugal e Espanha). Geolis $3,137-143$

Hooghiemstra, H., Stalling, H., Agwu, C.O.C., Dupont, L.M., 1992. Vegetational and climatic changes at the northern fringe of the Sahara 250,000-5000 years BP: evidence from 4 marine pollen records located between Portugal and the Canary Island. Review of Palaeobotany and Palynology $74,1-53$.

Jelgersma, S., Tooley, M., 1995. Sea-level changes during the recent geological past. Journal of Coastal Research, Special issue 7, Holocene cycles: Climate, sea levels and sedimentation, pp. 123-139

Komar, P.D., McManus, J., Styllas, M., 2004. Sediment accumulation in Tillamook Bay, Oregon: natural processes versus human impacts. The Journal of Geology 111, 455-469.

Loureiro, A., 1905. Os portos marítimos de Portugal II-Atlas. Imprensa Nacional, Lisbon.

Macías, S., 1992. O Garb-al-Andaluz-Resenha de factos políticos. In: Mattoso, J. (Ed.), História de Portugal, I-Antes de Portugal. Círculo de Leitores, Lisbon, pp. 417-429.

Mann, M.E., Bradley, R.S., Hughes, M.K., 1999. Northern hemisphere temperatures during the last millennium: inferences, uncertainties, and limitations. Geophysical Research Letters 26, 759-762.

Martínez-Cortizas, A., Pontevedra-Pombal, X., García-Rodeja, E., Nóvoa-Muñoz, J.C., Shotyk, W., 1999. Mercury in a Spanish peat bog: archive of climate change and atmospheric metal deposition. Science 284, 939-942.

Mattoso, J., 1992a. A época Sueva e Visigótica-As histórias do poder. In: Mattoso, J. (Ed.), História de Portugal I-Antes de Portugal. Círculo de Leitores, Lisbon, pp. 305-321.

Mattoso, J., 1992b. 1096-1325-Dois séculos de vicissitudes políticas. In: Mattoso, J. (Ed.), História de Portugal II-A Monarquia feudal (1096-1480). Círculo de Leitores, Lisbon, pp. 23-163.

Mattoso, J., 1992c. 1096-1325-Mutações. In: Mattoso, J. (Ed.), História de Portugal II-A Monarquia feudal (1096-1480). Círculo de Leitores, Lisbon, pp. 243-267.

Mattoso, J., 1997. Antecedentes medievais da expansão portuguesa. In: Bethencourt, F., Chaudhuri, K. (Eds.), História da expansão portuguesa I-A Formação do Império (1415-1570). Círculo de Leitores, Lisbon, pp. 12-25.

Moreira, J.M., 2002. A Cidade Romana de Eburobrittium-Óbidos. Editora Mimésis, Porto.
Natividade, M.V., 1960. Mosteiro e Coutos de Alcobaça, algumas notas para o estudo da sua agricultura. Unpublished Report, Instituto Superior de Agricultura, Lisbon, 196p.

Pita, C., Santos, J., 1989. Análise dos Temporais na Costa Oeste de Portugal Continental (1956a 1988). Technical Report 1/89A, Project NATO PO-Waves. Instituto Hidrográfico, Laboratório Nacional de Engenharia Civil, Lisbon.

Pita, C., Santos, J., 1992. Síntese de Dados de Temporais Ocorridos em Portugal Continental. Technical Report 14/92-A, Project NATO POWaves, Instituto Hidrográfico, Laboratório Nacional de Engenharia Civil, Lisbon.

Queiroz, P., Mateus, J., 1994. Preliminary palynological investigation on the Holocene deposits of Lagoa de Albufeira and Lagoa de Melides, Alentejo (Portugal). Revista de Biologia 15, 15-27.

Rodrigues, A., Magalhães, F., Dias, J., 1991. Evolution of the northPortuguese coast in the last 18000 years. Quaternary International 9, 67-74.

Shepard, F., 1963. Submarine Geology. Harper \& Row, New York.

Santos, L., Goñi, M.F., 2003. Lateglacial and Holocene environmental changes in Portuguese coastal lagoons: 3. Vegetation history of the Santo André coastal area (SW Portugal). The Holocene 13, 459-464.

Serrão, J.V., 1993. O Ambiente dos poderes - O quadro humano. In: Mattoso, J. (Ed.), História de Portugal IV-O antigo regime (1620-1807). Círculo de Leitores, Lisbon, pp. 49-69.

Serrão, J.V., 2004. Foi o século XVIII uma época de crise ou de progresso para a agricultura portuguesa? Seminários de História. Instituto de Ciências Sociais da Universidade de Lisboa, Lisbon 35p.

Solanki, S.K., Usoskin, I.G., Kromer, B., Schüssler, M., Beer, J., 2004. Unusual activity of the Sun during recent decades compared to the previous 11,000 years. Nature 431, 1084-1087.

Sousa, A., 1992. 1325-1480 - Condicionamentos básicos. In: Mattoso, J. (Ed.), História de Portugal II-A Monarquia feudal (1096-1480). Círculo de Leitores, Lisbon, pp. 313-389.

Sousa, F.L.P., 1932. O terramoto do $1^{\circ}$ de Novembro de $1755 \mathrm{em}$ Portugal e um estudo demográfico IV: Distritos de Leiria, Castelo Branco, Coimbra, Guarda. Aveiro e Vizeu. Oficina Gráfica, Lda., Lisbon.

Stuiver, M., Reimer, P.J., Bard, E., Beck, J.W., Bur, G.S., Hughen, K.A., Kromer, B., McConrad, G., Van der Plicht, J., Spurk, M., 1998. INTCAL98 radiocarbon age calibration, $24,000-0$ cal BP. Radiocarbon 40, 1041-1043.

Torres, C., 1992. O Garb-al-Andaluz-A terra e os homens. In: Mattoso, J. (Ed.), História de Portugal I-Antes de Portugal. Círculo de Leitores, Lisbon, pp. 363-383.

Trindade, J., 2001. Memórias históricas e diferentes apontamentos, àcerca das antiguidades de Óbidos, second ed. Câmara Municipal de Óbidos, Óbidos $311 \mathrm{p}$.

Turon, J.-L., Lézine, A.-M., Denéfle, M., 2003. Land-sea correlation for the last glaciation inferred from a pollen and dinocyst record from the Portuguese margin. Quaternary Research 59, 88-96.

Vaquinhas, I.M., Neto, M., 1993. Estruturas e conjunturas económicasAgricultura e mundo rural: tradicionalismos e inovações. In: Mattoso, J. (Ed.), História de Portugal V—O Liberalismo (1807-1890). Círculo de Leitores, Lisbon, pp. 325-337.

Zilhão, J., 2000. From the Mesolithic to the Neolithic in the Iberian Peninsula. In: Price, T.D. (Ed.), Europe First's Farmers. Cambridge University Press, Cambridge, pp. 144-182. 